\title{
What really matters for students in South African higher education?
}

\begin{abstract}
He sat at his desk for a few minutes, then drew some papers towards him and looked at them, reading through the words, understanding each one but not certain he understood what they intended to say. He set them aside, then pulled them back to read them again; this time, the sentences made sense to him, though he could see no reason why anyone would find their messages important. ${ }^{1(p .49)}$
\end{abstract}

Almost everyone who works in a university or research organisation has had this experience, and not only when reading institutional circulars or exam papers. But the experience has almost certainly increased exponentially in the face of what has been written about '\#Rhodesmustfall', '\#feesmustfall' and '\#outsourcingmustfall' over the past five or six months - along with the volume of analyses of these events, and of what other people have written about these movements. Yet at least three messages that emerge from the endless sentences are important, in this instance, as preludes to what really matters for students in the South African higher education system.

Firstly, there is the matter of how to sustain the financing of higher education institutions, without fee increases (and in some cases, without registration fees too) being levied and paid. Assuming that universities should, at the very least, be no worse off than they were in 2015 in view of the rising consumer price index - which applies to operating costs and to acquiring intellectual materials with a weak Rand - the value of the unpaid increases needs to be sourced. There is a scramble underway to attempt to ensure that this happens. At the same time, students (both revenant and new) will need support for the fees that do still have to be paid; for their learning materials; and, critically, for their living costs.

For a very few, this will come from their families, but for students from 'squeezed' middle class families, and from families who are unable to make any contribution to these expenses (taking account of the unemployment figure of 8.3 million South Africans - affecting close to half the population), the National Student Financial Aid Scheme (NSFAS) will have to do better. It will need more funding, and it will need to be better administrated, both within the Fund and within universities. The appointment of Sizwe Nxasana as the new Chair of NSFAS is a remarkably positive step - but turning the Fund around may prove to be a task at least as challenging as managing First Rand.

The second issue spirals around the debates regarding free education for all. This shift in the '\#feesmustfall' campaign was sparked by President Zuma's announcement last October that fees for 2016 would be capped at 2015 levels, stating that the government was understanding of the difficulties faced by students from poor households - and urged all students to allow the process to unfold to find long-term solutions. In response to this, he set up a Commission of Enquiry, none of whose members are educationists or economists, to investigate whether or how free higher education might be implemented for higher education students. Notably however, despite the costs of the student protests damage to university buildings, deferred examinations, and problematic registration processes this year - the President devoted no more than two or three sentences in his State of the Nation Address to higher education. It is perhaps fitting then, that one of the banners carried by students protesting outside the Union Buildings last year declared 'Time For Educated Leaders!'

Articles in the popular press by those who have addressed this issue range from those of serious economists (including Thomas Picketty) who indicate that free education for all is primarily a benefit to the wealthy; through to the damage that a state of financial scarcity does to sound educational decision-making; to the position taken by some who ignore economic reality and government expenditure patterns in order to claim that free higher education for all is undoubtedly possible; on to those who point to the failure of free higher education in other African countries. But in the face of South Africa's budget deficit and the fear of a junk bond status (and so higher borrowing costs), this seems to be a poorly considered position - the more so if the greatest benefits accrue not to the students who most need free education but to the economically better off.

The '\#Rhodesmustfall' movement, of course, was the public face of the third issue (and another, addressed below): the decolonisation and (or) the inclusion of indigenous knowledge in the curricula of all universities. Clearly, both the 'decolonisation' of knowledge and respect for, and the inclusion of, relevant indigenous knowledge in the curriculum, are issues of the greatest importance. They are not, however, unique to South Africa, nor - in many instances - are they new issues. Many departments of literature in South African universities have, for instance, been teaching African literature and not only on the basis of 'European' theories of analysis. This might not yet be true in all departments of philosophy, sociology, or history, for instance (although there are some examples), but the idea is not entirely new. What's more, there are some limits to the process: how might genomics, the general theory of relativity, gravitational waves or the 10-min saliva test for cancer be decolonised - or enriched by indigenous knowledge? This is not to suggest that there are no real issues at stake for curriculum revision, but the demands should not overlook what has been done, what can be learned from those practices, as well as the limits that exist if South African universities are to teach disciplines that are, in fact, respected elements of international research. Relating those respected research findings to local contexts will, of course, require a knowledge and understanding of local circumstances - but the core knowledge will remain as it is. Until South African researchers change it.

The three issues are highly significant. Recognising them, taking them seriously, and dealing with them in ways that are intellectually rigorous and honest, are all essential to the future of higher education - not in South Africa alone, but in many other parts of the global south and north.

Access to higher education - to any level of education, of course - is critical and affordability is too, because access without affordability has no meaning; and do not forget sound and relevant curricula and teaching skills. But what matters after those issues are addressed? What counts next? Probably the most important matters of all are those to which the earlier issues are the preliminaries. Why take the trouble to access higher education, at no or low cost, with changed curricula and teaching (issues that might well be matters for contention), if what is learned is of low quality? If the worst of the hurdles are removed, but the race is not worth the running, it is all to no purpose. So the most critical matter that counts next is the high quality of the content, of the science, and of the research offered by institutions and recognised as such, not just in Europe or the USA, but also, of course, in India, China or Brazil. Adam Habib, Vice Chancellor of the University of the Witwatersrand, and Chair of Universities South Africa, says:

\footnotetext{
There is a danger in this moment that if we allow the current populism to be unconstrained, it could result in a higher education system that enables access, but destroys quality. This is the history of the continent and it would be a tragedy if it were to be repeated. From 2016 onwards it is going to be a political and intellectual struggle between these two outcomes. ${ }^{2}$
} 
Sadly, as this Leader is being written, the populism, partly fuelled by the '\#Rhodesmustfall' movement, continues to be widespread, and completely misaligned with the fundamental needs of South African society. There are campus protests at four universities, some involving student arrests by police. The protests at one university included the burning of works of art of historical value and the fire-bombing of the Vice Chancellor's office and, at another, the destruction of a science laboratory for schoolchildren. The wealthy parent of one of the '\#Rhodesmustfall' 'activists' involved in the protest, who is the CEO of a state owned enterprise, claimed that this 'builds character' and that it would 'spark intellectual debate'. Really? These are serious, criminal, destructive activities. The hapless indulgence and dismissal of law and order on the part of a parent, however well-placed she or he is, cannot be ignored, because this tolerance contributes, collectively, to the problem of a social movement that serves its own self-interests - and nothing more than that. Yet another parent, who fought consistently for liberation and democracy, is silent regarding his daughter's destruction of public property.

The second condition that matters (if the first were not disheartening enough) is learning that ultimately leads to the opposite, the creation of social value. If earning a worthless degree is a useless exercise, then earning a degree that is of no personal or social use is worthless. This is most definitely not intended to suggest that higher education must be nothing other than an instrumentalist process: being employable means, more than anything, having high level analytical and communication skills, the ability to solve problems, to be innovative, and adaptable. It is not just about learning content, but also about developing flexible talent, and about how to make the most of those skills in new and challenging circumstances. In some instances, problem-solving and adaptability skills are of greater value than content that might have a brief half-life.

The third 'what matters' is learning, and then graduating with, knowledge and values that prepare students to be successful, confident world citizens. This does not imply that graduates should leave South Africa (although they might well choose to do so). More significantly, it points to the fact that South Africa's future depends on being part of a wider world in which countries, including South Africa, are generating new ideas, applications, and economies that are the foundation of our own national survival - and of the world.

There's a great deal at stake, more than can immediately be imagined, for higher education in South Africa, and so also for young South Africans (poor or rich) who enter universities; and even more at stake when it comes to their contributions to their own and the country's success and prosperity. We cannot afford to ignore the immensity of the consequences if we do not do everything possible to get higher education right.

Quidnunc?

\section{References}

1. Leon D. Uniform justice. London: Heinemann; 2003.

2. Habib A. Goals and means - Reimagining the South African university University World News. 2016 Feb, Issue 400. Available from: http://www. universityworldnews.com/article.php?story $=20160211070052665$ 